\title{
Deconstructing Racist Processes of Social Discrimination Through Education
}

DOI: https://doi.org/10.32870/dse.v0i13.233

\section{Rodrigo Zárate Moedano}

Translation by Joshua Sol Lewis joshua.sol.lewis@gmail.com

\begin{abstract}
This article describes a participatory process of research and education with an ethnographic approach conducted with undergraduate students of various educational areas, from diverse ethnic and geographical origins, sexual orientations and socioeconomic levels, in the main campus of Universidad Veracruzana, a Mexican public university. Based on the concepts of social imaginary, identity and social discrimination, this article analyzes the symbolic framework that justifies inequalities within the nation, and how it operates. Through an educational program that interweaves popular education with critical approaches to intercultural education and media education, students analyze representations of "indigenous", "white people", "black" and "Mexican" subjects, contrasting their differences and making inequities visible. Data collection was conducted through focus groups, in-depth interviews, participant observation and life stories, to analyze how the students' imaginary structures their identity construction processes. Keywords: social imaginary, identity, racism, intercultural education, media education.
\end{abstract}

\section{Introduction}

The Mexican Constitution guarantees equality for all citizens. Nonetheless, social practices systematically contradict this legal principle, with certain social groups enjoying privileges or suffering disadvantages. In this framework of inequality it is the native groups who perennially occupy the lowest positions in the country's socioeconomic structure. In this sense the decolonization of Mexico has been deemed "incomplete" (Bonfil, 2010: 11), with the country achieving independence from Spain but "failing to eliminate the internal colonial structure"; the groups in power have continued to reproduce the colonizer's perspective from their positions of privilege.

Within this order of internal colonialism (González Casanova, 2003: 3), the name of "Indian"1 has been assigned to dominated native groups in an attempt to erase their vast diversity and impose a foreign political, economic, and social system that is radically antagonistic to native systems.

* Bachelor's in Communication with Master's in Educational Technology and advanced studies in the History of Film, doctoral candidate in Educational Research. Professor and audiovisual producer at Universidad Veracruzana. Topics of research: the reproduction of racism, the link between media and intercultural education. E-mail: rodrigo.zarate.moedano@ gmail.com

1 Following the theoretical, historic, and political position of this article, all ethnic and national categories used throughout will be qualified with scare quotes to emphasize the arbitrary nature of their construction (for example, "indian", "black", "Mexican", and "Spanish"). 
Native groups thus have no government of their own and any political decisions they make must adhere to regulations imposed by the central government. Further, the market economy places them under severely exploitative conditions with low salaries and little social recognition.

Within this system, the identity of "indian", or "indigenous", is laden with negative prejudices. Six out of ten persons who identify as "indigenous" see discrimination as their principal problem and prefer to not openly identify themselves as such when seeking work (CONAPRED, 2011). Thus conditions of marginalization experienced in everyday life directly dovetail with recurring structural processes of discrimination.

The purpose of this article is to, on one hand, describe the contours and dynamics of the symbolic framework that justifies the inequalities experienced by those who are or appear to be "indian" or "indigenous", and on the other show how this framework can structure processes of identity construction and analyze in what ways a collaborative process of research and education can bring about the deconstruction and resignification of student imaginaries and identities. For this purpose I will base my analysis around the cases of two female students who identified as "nonindigenous", even as they recognize family members as "indigenous"; two students who, due to their academic history and political activism, were part of the critical vanguard of our focus group. Both were seniors, sociology majors, and activists in a feminist collective: Flor, native of Chetumal, the capital city of the state of Quintana Roo, and Raquel, native of Chicontepec, a small city in the northern part of the state of Veracruz. ${ }^{2}$

\section{The process of constructing knowledges}

The research that this article is based on had an ethnographic approach and was developed in collaboration with the subjects of the study: university students. The object of analysis was the relationship between the students' imaginaries concerning the identities that constitute the nation's "foundational myth", on the one hand, and their processes of identity construction, on the other. Fieldwork took place within the framework of an Audiovisual Production workshop that I designed and implemented with the explicit aim of creating a setting for doctoral research. ${ }^{3}$ The workshop was entitled "Documenting Diversity" and was given throughout one semester, from February to June 2015 on the Xalapa campus of the Universidad Veracruzana (UV).

Presuming that as instruments of power dominant imaginaries are filtered from the top down, issuing from social groups that occupy positions of privilege, I chose to work with university students because in Mexico access to higher education is the exclusive privilege of a minority which structurally is not "indigenous", or if it is, probably does not recognize so publicly. I also chose

2 It was agreed upon with students that fictitious names would be used to preserve anonymity.

3 With the aim of explicitly stating the positionality from which research was conducted, I will reject classic scientific rhetoric that is impersonal and aseptic and instead employ the first person singular, thus recognizing my participation in the process as part of a "we", a group of "Mexicans" molded by a racist national imaginary. 
to develop the research in a public university such as UV because since 2009 its institutional work programs have established interculturalism as one of its guiding principles, envisioning in one form or another the adoption of an intercultural focus in all programs across the board and the support for students in unfavorable conditions due to different forms of exclusion, in particular "indigenous" students. Lastly, I chose to develop the program in the Xalapa campus because, being one of the most important public centers of higher education in the Mexican Southeast, and Xalapa being the central headquarters of state and university power, students are drawn not only from different parts of the state of Veracruz but also from different states in Mexico and in a smaller degree from foreign countries; in sum, students have very diverse identity backgrounds.

A complementary objective of the workshop was to prompt students to compare and contrast representations that are radically opposed to the identities constituted by the nation's imaginary. Thus the goal was to create favorable conditions for students to reflect, individually and collectively, on how the subjects of "indigenous", "Spanish/white", "black", and "mestizo" are represented in narratives issuing from media such as film, television, and the internet, as well as those transmitted by school and the family.

In this vein the workshop design and implementation were theoretically and methodologically inspired by the pedagogy of Paulo Freire as well as by critical perspectives on intercultural education (Walsh, 2010) and media education (Kellner and Share, 2007). The group was formed in January 2015 based on a call I made to undergraduate students to participate in a workshop entitled "Documenting Diversity". The call was amply publicized through UV channels of electronic communication. 55 students responded, of which 43 fulfilled the requisite of having a personal selection interview with me.

In the interview I described my doctoral research project in general terms and informed candidates that their participation in the workshop implied participation in my research. The agreement was that the workshop would be free in exchange for their collaboration as research co-authors and "owners" of the information gathered based on observing their practice, as well as for their participation in giving feedback on the interpretations that I voiced in reflexive focus groups.

To orient the selection process, students filled out a survey concerning general information (age, gender, major, year of study), socioeconomic level, ethnic/geographic background, sexual orientation, and availability. The guiding criteria of the selection process was to gather the most diverse group of 20 students possible in terms of majors, genders, sexual orientation, and ethnic/ geographic background. ${ }^{4}$

4 Of the 43 students interviewed (enrolled in 23 different undergraduate programs) I selected 20 (enrolled in 13 different undergraduate programs in the 6 academic disciplines in which the UV is administratively subdivided: Arts, Natural Sciences, Health Sciences, Economic Administration, Humanities, and Technology). Of those selected, 12 were women and 8 men. 12 identified as heterosexual and 8 as homosexual or bisexual. 4 stated that their grandparents spoke a native language. One identified as Afro-Mexican. 6 were from the capital of Veracruz, Xalapa, 7 were from other parts of Verazcruz, and 6 were from other states (Oaxaca [2], Quintana Roo [1], Coahuila [1], Mexico City [2]). Based on the survey I inferred socioeconomic conditions and evenly selected students with upper, middle, and lower class backgrounds. 
As part of workshop activities I formed 4 thematic focus groups in which students analyzed how different narratives in different ways represent "indigenous", "Spanish/white", "black", and "mestizo" subjects. On the premise that all knowledge is contestable, the goal of the focus groups was to undertake the deconstruction of the representations being analyzed; in other words, to develop subversive, non-dogmatic readings that might fragment dominant representations, seeking out "marginalized phenomena, previously repressed by hegemonic discourse" and thus generating alternative narratives (Krieger, 2004: 184).

The aim was for students to develop critical eyes and ears in order to identify how the components of a given representation are and can be articulated, and to subsequently create different types of signifiers that might facilitate a break with the dominant, "sedimented", and naturalized interpretative logic (Molina Valencia, 2013: 50), thus rescuing and thematizing peripheral meanings that are left out of dominant representations, commonly thrown out and habitually hidden at the margins.

In order to contrast and complement the testimonies that emerged from the focus groups and my field notes, I carried out two series of in-depth interviews. Based on the information gathered therein, I wrote up a "life story" of each of the 6 students that I picked as cases of special interest. This task was based on the idea that in reconstructing their biographies I would be able to identify their "perceptions, interests, doubts, orientations, landmarks, and circumstances that - from their respective perspectives - have significantly influenced who they are and how they act" (Bolívar and Domingo, 2006: 6). The aim was to analyze in what way their individual experiences correlate to the concrete socio-historical contexts in which their trajectories have developed. In particular, I wanted to analyze in what fashion their life experiences in school and family have shaped their imaginaries of identity and alterity within the nation-state framework.

I classified and organized the information gathered in the transcriptions of the focus groups and in-depth interviews and identified recurrences, divergences, and relations from the perspective of critical discourse analysis (Van Dijk, 2003). Further, throughout the process of knowledge building, I sought to identify, from an ethnographic perspective, the relationship between subject practices and the institutional framework that regulates them; that is to say, to observe, interpret, and describe subject practices in a situated fashion so as to make visible the "not evident" and "document the not-documented" (Rockwell, 2009: 21); in this case, the social phenomenon that is recognized by intellectuals but that is denied by political institutions and in everyday life: the racism that shapes the nation's imaginary and national identity.

In a complementary and parallel manner, in order to contextualize the experiences of students within the framework of the nation's history, I reconstructed how the colonial domination of the "Other" has been reproduced. Lastly, with the aim of developing a process of double reflexivity (Dietz, 2012), I presented students with my research conclusions, to which they reacted in two focus group sessions. This article is based on the perspective that emerged from this dialogue between students-researchers and facilitator-researcher. 


\section{Historic antecedents of the study}

\section{Colonial domination of the other}

Before analyzing the cases of Flor and Raquel, I consider it very relevant and pertinent to describe the large-scope historical context in which they are framed. It should be pointed out from the start that from the very first encounters between the native people of America and European conquistadors, two radically different imaginaries clashed. As with all social interactions in contexts of diversity, each group identified distinctive characteristics between "them" and "us" and interpreted differences between the two identities based on historically developed ways of knowing the world.

From the perspective of the conquistadors, the daily life of Native Americans was marked by barbaric, savage, and primitive practices which had been left behind centuries ago by the advanced civilization of Europe. Consequently the invaders felt they were from a superior, more civilized community than the "indians", and from that position they began to fight for political, economic, and religious control over the huge and wealthy territory that would come to be known as the Viceroyalty of New Spain.

After completing the conquest the victors imposed their model of civilization as the only path to development, as well as the grammar of identity/alterity that guaranteed the reproduction of that model, i.e. the cultural patterns from which they structured their perception of self and other and subsequent interactions with groups with diverse identities (Gingrich, 2004). In becoming the symbolic infrastructure, this grammar gave form to the social system of castes which instituted a hierarchy of structured domination that revolved around an opposition between civilization and barbarism.

Within this imaginary the purity of Spanish blood was the guarantee of the reproduction of civilization, whilst the "contamination" produced by mixing it with the blood of "indians" and "blacks" weakened it. Thus, based on the relative worth of "indian", "black", and "peninsular [born in Spain]", the caste social system assigned a different status to each respective identity configuration (Bonfil, 2010: 40). Thus for three centuries the identity of "peninsular" was located at the top of a hierarchy that gave privileged access to economic resources, political power, and social recognition, while limiting the same for those identified as inferior - "criollos" [whites born on American soil], "indians", "blacks", and other "mestizo" castes - thus guaranteeing the perpetuation of the system of colonial domination.

In this context, according to the imaginary of the era, the "criollos", although they were children of "peninsulars", were second-class "Spaniards" due to the stigma of having been born on American soil (Anderson 2005: 95). "Indians" were believed to be child-like savages being taught the basics of civilization, incapable of taking care of themselves without the guidance of "superior" subjects. "Blacks" had even less social recognition than "Indians", as they were not even considered as humans but rather as animals. Members of "mestizo" castes were classified with varying degrees of degradation and undesirability depending on how much "indian" or "black" blood they had. 
Within this grammar of identity/alterity that structured the social caste system, it is important to point out that the degree of perceived "whiteness" conferred increased superiority and respect on a "mestizo" subject, while on the other hand features of "brown-ness" and "black-ness" generated scorn and contempt. Thus to be a descendent of "peninsular" and "indian" was preferable to being a descendent of "peninsular" and "black" (Gómez y Sánchez, 2012: 34). In this fashion the social caste system instituted and legitimated what Giménez (2007: 38 and 39) calls social discrimination: the reciprocal but unequal exchange of evaluations between subjects or groups that occupy asymmetric positions on the social ladder. An exchange which, in a context of diversity, translates into unequal treatment for subjects and groups with different identities, as well as negative actions by dominant groups towards dominated groups.

As the privileged group, the criollos appropriated the symbolic and material resources necessary for an attempt to bring the social order that they had imagined to reality (Anderson, 2005:93). In 1810, after three centuries of Colonial Spanish domination, the dominated population of the Viceroyalty of New Spain, led by a group of "criollos", took up arms to take political and economic control away from "peninsulars" and install a national independent state.

\section{Colonial domination of the other in the nation-state}

The "criollos" who led the fight for independence in the $19^{\text {th }}$ century were educated and imbued with the scientific developments generated in Europe during the Enlightenment in the $18^{\text {th }}$ century. The main references during their political struggle were two major events that occurred during the end of the $18^{\text {th }}$ century and which embodied the culmination of Enlightenment ideals: the Declaration of Independence of the United States of America (1776) and the French Revolution (1789).

As a result, upon achieving independence in 1821, the social order that was instituted was based on European traditions of thought. However, even though the new republic abolished slavery, established the equality of all citizens, and officially abandoned the use of caste names to identify subjects, the grammar of identity/alterity inherited by the colonial caste system was not substantially altered in its appreciation of "whiteness".

The grammar of the Mexican state gave continuity to the positive evaluation of "whiteness" as a token of civilization and modernity, in opposition to the negative evaluation of "dark skin" or "blackness" as tokens of the uncivilized and primitive. This continuity was most likely due to the fact that imaginaries don't change instantaneously by mere legal degree but rather by a gradual, prolonged process based on social interaction. Even when imaginaries undergo radical changes over time, they also experience continuities, since "all symbolism is built on the ruins of previous symbolic structures and utilizes their materials" (Castoriadis, 2013: 194).

Nonetheless, it is pertinent to point out another potential cause of continuity, the fact that conservative political thought at the time had Carl Von Linnaeus' Systema Naturae (1753) in its catalog of admirable books. In his book, Linnaeus classified the human "races", and after combining 
observations, measurements, and empirical comparisons of each "racial" group with judgments of moral value, he concluded that the "white race" was superior, since it held the most "congenital" virtues (Gómez and Sánchez, 2012: 41-42).

Later, during the second half of the $19^{\text {th }}$ century, the domination of the Other in the young Mexican nation was justified by using "biological racism" as an ideological tool. This line of thought established a dividing line between biologically superior and inferior humans, basing itself on Linnaeus' classification of human "races" and on a social interpretation of the theory of evolution put forth by Charles Darwin in The Origin of Species (1859).

Social Darwinism held that mechanisms of social evolution were active in the context of capitalist competition through which only the most capable survived. Concomitantly, with its base in Social Darwinism, "eugenics" advocated the artificial selection of the most apt, i.e. the "cleansing" of human populations by controlling their reproduction, thus allowing the procreation of subjects with "desirable" features of identity while impeding the procreation of those with "undesirable" features.

So even while the project of nationalism sought a sentiment of fraternity and solidarity that could blur ethnic differences, the project of racism sought to accentuate those differences and psychically abuse the Other to the point of being symbolically and materially dominated. The result was a state racism, a racism that elites enforced to defend themselves from "biological threats" that were being reproduced in the lining of the social fabric (Gómez Izquierdo, 2005: 125).

With this goal of creating a sentiment of belonging among social groups who were previously divided in castes, the Mexican elite established mestizaje ("racial mixing") between the "peninsular" father and the "indian" mother as the nation's founding myth, the common origin of all Mexicans. And with the aim of continuing the relationship of domination over native groups, they constructed the "indian" as inferior and undesirable for national progress, such that to be part of the nation, native groups had to "de-indianize" (Bonfil, 2010) themselves, i.e. transform themselves into "mestizos".

Thus this national imaginary, upon positing homogeneity as its goal, re-signified the "mestizo" identity, which went from being a degrading one within the caste system to being the model of a national identity. On the other hand, "blacks" were constructed as a historical accident, that is, as slaves which existed at one point but "disappeared without a trace" following independence.

Meanwhile the "indians" were constructed as beings with inferior intelligence, inimical to reason and anchored in a primitive mentality that generated superstitions, fanatical atavisms, and spiritual backwardness, the latter of which upheld a barbaric religion. Thus they were constructed as an obstacle to the consolidation of the nation as a modern country. Consequently, in order to "better the race" and "palliate the cultural and technological lag", the State pushed for foreign immigration from Europe (Castellanos Guerrero, 2005: 106). 
For this reason, once the new dominant grammar of identity/alterity was instituted in the national discourse, the subjects identified as "indians" or "blacks" had much less access to economic resources, political power, and social recognition than those identified as "mestizos". Apart from being mestizo, any given subject had a higher chance of accessing a position of privilege in national life if he had lighter skin.

\section{Consolidation and deconsolidation of the mestizo nation}

As a consequence of the "order and progress" agenda pushed by the Porfirio Díaz regime, it seemed as if the "indian" had begun to irretrievably disappear from the national map. With the advent of the Mexican Revolution, however, native communities rallied to the Zapatista call for "land and liberty", thus defending their identity and reclaiming the territories that permitted the continued reproduction of their cultural traditions. Nonetheless, it wasn't the Zapatista nation-building project that won out, and the nation's development continued to be aligned with the Western civilization project, as well as most of its discourse of identity/alterity.

Proof of this is the continuity of the "anti-indian" racism of the identity politics pushed by elites before and after the Revolution (Gómez Izquierdo, 2005: 122-123), in particular the construction of "the indian" with racist prejudices and stereotypes that projected him "not only as poor, passive, and backwards, but also as criminal, fanatic, a potential threat, and vicious", thus justifying his subordination by stigmatizing his cultural difference as an encumbrance.

Once the post-revolutionary period of instability and turbulence concluded, subsequent governments proceeded to consolidate their power and control over territory and communities, orienting their actions around the process of incorporating the "indians" into the nation. In this context, the creation of the Bureau of Public Education (SEP) in 1921 established the centralized national education system, which institutionalized "indigenism" to "redeem the indians" and reinforce the "mestizo" identity. This "redemption" consisted in replacing native identities, normalizing Spanish as the only national language, and wiping native peoples' "primitive dialects" from the map.

The historical narratives concerning the founding of the nation took up the perspective of the Porfirian elites, projecting the Conquest as a benefactor in relation to savage and bloody pre-Hispanic Mexico. This perspective was based on the point of view of the conquerors - the testimonies written by soldiers, chroniclers, and Catholic priests - all of which to some degree reproduced the grammar of identity/alterity of the Conquistadors (Gómez Izquierdo, 2005: 143-144).

Later, beginning in 1960, free textbooks produced by the State have reproduced a particular construction of the nation for public and private schools throughout the country. These books define the common beliefs, norms, and values that orient the practices of Mexican subjects, thus operating as a referent for processes of construction of identity and alterity (Ramírez Lozada, 2003: 185-186) and legitimizing and naturalizing the power of dominant groups.

The official national history has confirmed its racist and colonialist vocation, projecting the "mestizo" as a savior of the biologically, culturally, and morally inferior "primitive" subjects. It 
has prescribed mestizaje as the path to a certain social recognition, so that "indigenous" who have rejected or haven't become "mestizos" have continued to experience stigmatization, exploitation, and racist paternalism from "whites" and "mestizos" (Gómez and Sánchez, 2012: 23), and the "indigenous" identity has been constructed as undesirable and contemptible.

The teaching of this version of history constitutes a "cultural invasion" (Freire, 2005), since the imaginary of the oppressed has been shaped by those in power, preventing their autonomous development instead of transforming the imaginary that justifies oppression. The national State's pedagogical action has focused on convincing subjects of their "intrinsic inferiority" in relation to dominant group subjects. It is important to point out that subjects tend to naturally give a positive value to their identity, thus boosting self-esteem, group pride and solidarity as well as the will and capacity to resist excessive penetration of foreign elements of identity. Upon facing systematic negative representations of their identity, however, be it on the basis of unfavorable comparisons with other identities or because they've been "instilled with stereotypes and stigmas", subjects easily come to experience "frustration, demoralization, inferiority complex, dissatisfaction, and crisis" (Giménez 2009: 44).

Finally, within a world order characterized by the globalization of neoliberal policies at the end of the $20^{\text {th }}$ century, the Mexican state implemented a series of reforms that buttressed conditions of domination experienced by native groups. The 1992-93 school year was declared "year of the study of Mexican history" and history books were distributed that interpreted the past according to contemporary political objectives. The "indigenous" presence in national history was rendered even more invisible, the space dedicated to the role of Zapata and small farmers in the Revolution was reduced as well as the extent of their grievances, and urban life in contemporary Mexico was overly exalted (Ramírez Lozada, 2003: 220-221).

In this context the actions of the Zapatista Army of National Liberation (EZLN) came to question the legitimacy of the Mexican state and the racist national imaginary that it advocated. The State was put to the test, and even though the existence of the EZLN destroyed the illusion of the "mestizo" nation, the groups in power rejected the horizontal dialogue between "mestizos" and "indians" that was proposed by the San Andrés Agreements (Gómez and Sánchez, 2012: 113). Facing the demand for change from "our indigenous peoples", the "mestizo" political class continued the State's structural and systematic effort to maintain colonialism as the engine of national development, thus denying "indigenous" peoples the right to exist differently within the nation.

\section{Deconstructing and resignifying identities within the national framework The case of Flor}

Flor was born in December, 1990 in Chetumal, Quintana Roo, a city of 150 000. She is the only child of a single mother, but she grew up in a large extended family in a house that included her grandparents, an aunt, and a cousin. Unlike her grandparents, her mother and her mother's siblings 
achieved higher education. Her mother has a bachelor's degree in business administration and works as a federal government employee with the Mexican postal service, while her aunts work as teachers in secondary education.

I conducted two interviews with Flor on March $4^{\text {th }}$ and June $8^{\text {th }}$ of 2015 in the classroom where we held the workshops. In the first interview I asked her to tell me about her experiences with her family and how the latter may have influenced her definition of who she is. She began by describing her family as a "matriarchy", "very Catholic" and "united" by a strong feeling of "community and belonging". She told me that she is the first generation from Quintana Roo, her family having moved from Yucatan to Chetumal for "work and more opportunities".

Based on the information she had given during the selection interview, I knew before our interviews that neither she nor her mother spoke Maya, but that her grandparents and aunts did. Thus when I considered it an appropriate moment I directly asked her: "Do you know why your grandparents didn't speak Maya to your mother and her siblings?" Flor responded, "Yes, because they wanted their children to go to school, to get a bachelor's degree, and all of that; and one was looked down on if one spoke Maya because... it was seen as being ignorant".

She told me that her aunts learned Maya "in this trend of recovering one's language" and had taken classes to put it in practice in their places of work: Telesecundarias [rural schoolhouses centered around pre-recorded video lessons] in Mayan communities. She shared with me that in this same attitude of recovering what was lost, she wants to learn Maya: "I feel like I need to learn it... that it is part of me... we haven't wanted to face it because we were taught to reject it, because to speak Maya is a sign of being ignorant".

Here the judgment of "ignorant" was connected with a rural background and lack of education. In this vein I asked Flor to evaluate more specifically what categories led to this judgment. "Because of the concepts we have. I think of an indigenous person as someone who's never left his/ her community, who doesn't know how to move about in a city, who has little education, is timid; these are the first things that come to mind when I read the word, 'indigenous' - someone who has to be protected". In the second interview, I asked her, "When you come to a new place and you're with a group of new people, how can you know if someone is Indigenous?" She responded that it was very difficult to respond to that question: "How I can I answer it without falling back on the stereotypes that they've taught us, which is the easiest way to tell if someone is indigenous - 'look how they're dressed, how they're talking, if they're selling something"'.

Based on narratives issuing from the family, Flor constructed certain "typical" features of "indigenous" identities which lead to low social recognition and insulting attitudes. She remembers, for example, that her mother would make fun of her for wearing Yucatan's "traditional" blouses, saying, "Wherever you go, they're going to treat you based on what they see"; with sarcasm and disapproval her mother would call her "Rigoberta Menchu". In describing her mother, Flor indicated that "she doesn't wear that type of clothing", that "she is a woman who dresses up a lot and uses 
a lot of makeup... she tries to be very formal... a typical woman who works for the government". Flor identified this social pressure as the definitive reason that she stopped wearing those blouses that she "loved".

In another context, based on practices that she came into personal contact with in school, she constructed "the indigenous" as the object of insults and social discrimination. In our second interview she remembered that in middle school it was routine for her classmates to insult each other using expressions such as "you're an indian", or "goddamn indian". And in the first interview she remembered how in high school she would meet people who treated her "differently, in the sense that they felt they didn't have to treat you respectfully because of how you look... so... I started to feel like I'm not pretty and to have a low self-esteem".

Flor also recalled that her lack of self-esteem led her to consider herself aesthetically inferior to "light-skinned" subjects and to feel "like an insect" next to those who were so "tall and stunning", and to even define who she could or could not have a romantic relationship with. She remembers thinking things like, "I'm not even going to go after him because he's not going to notice me... because he's going to notice only the pretty girl" who doesn't look like an "indigenous Maya", which is how Flor describes herself.

\section{The case of Raquel}

Raquel was born in September, 1991 in Chicontepec, Veracruz, a city with little more than 50,000 inhabitants. She grew up in that city in a nuclear family, being the second of three daughters. Our first interview took place on March 1 ${ }^{\text {st }}, 2015$, a Sunday morning in a park she suggested close to her house in Xalapa.

On that occasion I asked her to tell me about her family experience and how that may have affected her definition of who she is. She told me that her parents are originally from Piltepeco, a small village in the state of Hidalgo, that they speak Spanish and Nahuatl, and that they both were the first in their respective families to achieve higher education. They come from campesino (small farmer) families and their entire education from elementary school on was obtained in public boarding schools for "indigenous" children. Their access to education enabled them to better their life conditions, leaving behind the uncertainty and marginalization of agricultural work in their village to enjoy the stability and prosperity of salaried work in the city.

Unlike their parents, Raquel and her sisters only speak Spanish, which she explained was due to the education that her parents received in the Mexican education system, where they were taught to scorn the characteristics of their "indigenous" identity. She began by telling me the story that they have told her, that in their elementary boarding school they were systematically punished for speaking Nahuatl: "they were severely impacted from being punished for speaking Nahuatl". 
She later shared with me that her father has always sought to "distance" himself from his "indigenous" identity, which was why he decided to break with the reproduction of Nahuatl as a first language in his family: "When they got together and had children my father told my mother not to teach us Nahuatl because it wasn't good for anything". Nine months after this first interview she synthesized this idea in one of the focus groups that took place in November, 2015: "My family tried to erase our indigenous past because of the nationalist discourse that the indigenous is inferior".

When I asked her what her position is on the matter, she responded by describing Chicontepec and Xalapa, the two cities where she has lived, as two environments where it is in fact useless to be able to speak Nahautl, as the dominant language is Spanish. She also recalled that the classmates she had in middle school who were from rural communities "didn't speak Nahuatl and weren't interested in speaking it". This made her think: "If they're supposed to speak it and do not, I don't see why I should speak it".

Based on an analysis of all the information gathered in the interviews, it seems that Raquel sees that her having been able to enjoy certain privileges in comparison with her classmates came as a consequence of her parents being professionals; for example, growing up in a city instead of in a marginalized rural community with limited access to public services; or having an encyclopedia in her house and being able to vacation in Xalapa, a city where, along with her sisters, she had the opportunity to go to high school and college.

It seems as well that her father, seeing the "indigenous" identity as an ignominious burden, has used all of the social and economic capital at his disposition to give Raquel and her sisters life experiences that could deepen the break with "the indigenous" and with small village life. In our second interview, speaking about the thesis that she was writing, "Education and Empowerment for Indigenous Women: Trajectories in Universidad Veracruzana", she admitted that she sees that socially the "indigenous" identity is a stigma that "naturally" wants to be hidden, even though she doesn't approve of this.

In searching for subjects for her research, Raquel said that she had the hypothesis that "because of the stigmatization of their communities", it would be difficult for many subjects to recognize their "indigenous" background in the university context. She recalled thinking that it would be uncomfortable to directly ask "if they identified themselves as indigenous women". However, she did just that and the reactions surprised her: "Of the six that I interviewed, upon asking them if they identified as indigenous they responded yes; this surprised me, I didn't think that would be their answer".

Analyzing the information given, it seems that the "stigma" discussed by Raquel is based in large part on the identification of features of "indigenous" identity as a trigger for discriminatory practices, as exemplified in the experience of her Nahuatl-speaking parents in the Hispanicizing school system or in memories of her father, presuming to be socially more powerful for having 
"studied", acting arrogant and with little solidarity with the campesinos who sought his consultation as an agricultural engineer.

\section{Deconstructing and resignifying identities from the classroom}

The focus groups were "spaces for free thought", dialogues not free from conflict, with perspectives from diverse socio-historical, disciplinary, and political contexts. In these spaces, systematic and organized reflection, individual and collective, was generated, a dialogue that allowed the experience of multiple perspectives on identity and alterity.

In the focus group concerning how "the indigenous" is constructed, which took place on March $12^{\text {th }}, 2015$, I started by showing the participants a series of images taken from movies and shows on television, dramas and comedies, as well as newspaper headlines. I asked students to recall narratives about the practices, experiences, lives, and cultures of indigenous groups, thus generating many different images and anecdotes that had been heard, observed, or experienced by the students.

Later, we compared and analyzed radically different representations of "the indigenous": one, a tourism commercial produced by the government, and the other a short documentary about a rock group. ${ }^{5}$ Flor pointed out the difference between the positions from which the two texts were constructed: "Whilst one tries to say from above, from the State, 'this is Oaxacan traditional culture,' the other shows you from below what the people themselves are showing as their culture... we can do whatever we want, we are making our culture, we are empowering ourselves".

In general, all the students agreed that the government advertisement represented all the "indigenous" subjects as subaltern to the tourists with European features. Celeste, an English major, summed up this idea: "Instead of conveying the idea of becoming part of their culture, it's as if they're saying, 'here are your slaves who will attend to you"'. Students also agreed that the native people were represented as decorative pieces for tourists' enjoyment. In this vein Antonio, a Computer Systems Administration major, said, "You go there to see them as a tourist attraction, not to be with them... like, not to be a participant, but like going to a zoo to watch". He then asked: "What concept do we have of the 'indigenous?' Are they here for our entertainment or as members of the same nation?"

Hector, a Hispanic Literature major, upon contrasting the visual and audio features of the two narrations, made a statement that everyone agreed with: "In the commercial there are no faces or voices... but in the documentary the subjects have a face, and not only a face, but also a personality, because they present themselves in front of the camera with their face, their clothes, and a music

5 The commercial (2014) was a promotion for the Guelaguetza, a local celebration that celebrates the iIndigenous" cultures in Oaxaca (https://youtu.be/yxkEIU9orIM). The documentary short, titled Hamac Caziim: Fuego Sagrado (2007), is about a rock group made up of members of the Comcaac, a native group from the state of Sonora (https://vimeo.com/107828518). 
that they probably chose to represent themselves... they have a voice in their own story... why they are doing what they're doing. In the commercial nobody knows why they are doing what they're doing - they're just there".

All agreed as well that they had more empathy for the people in the documentary short than for those in the commercial. This was synthesized by Tania, a Pharmaceutical Chemistry major: "putting the indigenous as a protagonist, as an actor, makes you feel connected to him...you even want to enter that situation and be part of it...none of us wants to be the little indian that appears in the soap opera as a secondary character, but we do want to be protagonists, don't we?"

I consider it significant that students coincided in pointing out that in television programs, the supposedly "indigenous" characters tend to be acted by "non-indigenous" actors, provoking Hector to say, with a bit of exaggeration, that it is common "for the indigenous character to be played by a dude like William Levy", a blond actor with blue eyes. Meanwhile Irasema, a Photography major, recalled a series of commercials commemorating the 200 year anniversary of Mexican Independence: "they were commercials about the indigenous woman, but the women were super European... dressed as indians".

I think it is significant that both Flor and Raquel indicated that before participating in this workshop they had never systematically reflected on the differences between televised representation of "indigenous" and "Spanish/white" people, despite being feminists, sociology majors, and having grown up watching soap operas for leisure.

In terms of the processes of deconstruction and resignification of imaginaries and identities provoked by the workshops, Flor mentioned that the focus groups brought her to "think, reflect, and deconstruct", and subsequently see "that there are different types of beauty". This realization led her to feel more self-secure and question her previous tastes: "Before, when I saw a light skinned boy I would be like, 'wow'. But not anymore, it's not the same, and I think that was the first and most sudden change that I experienced".

However, Flor indicated that the process of change has been subtle rather than radical, consisting mostly in posing questions to herself and beginning to forge a different way of seeing, listening to, and understanding the world: "I can't say that in these months I've become a completely different woman, but... I continue to question myself, it's like I've received a little push and that's where it all starts... paddle, paddle, paddle, and you start to change" (E2, 08062015).

Due to this new way of looking at the world, Flor remembered that after analyzing the Guelaguetza commercial, she realized that theme parks such as Xcaret feature similar representations of "the indigenous" in order to promote the sensation of "how nice it is to be Mexican". On become aware of his, she changed the value she put on these types of theme parks and representations: "I said to myself, damn, I used to love that theme park and now I'll never see it with the same eyes, I'll never be able to go there and enjoy it like before" (E2, 08062015). 
On her part, Raquel reflected that her participation in the focus groups contributed to "taking her out of the bubble" and confronting her with difficult voices that took her out of her "comfort zone"; the workshops led her to "check" what she had before taken as fact and to question points of view "that I thought were fixed", and to realize that "these things that we believe are so sure in our lives... and they can be challenged" (E2, 23062015).

She was in agreement with almost all of her workshop peers in saying that almost all of the workshop debates led her to pay attention and use her analysis capacity on topics, situations, and representations that she had never reflected on before and which led her to see "things which may seem obvious" and to fix her attention "beyond the superficial". Further, she pointed out that her participation had brought her to be more aware of how the specific context from which she experiences life impels the shaping of specific imaginaries: "My thoughts are not detached from the reality in which I live, so if I think something, there's a reason, this is what I realized in the workshops" (E2, 23062015).

She explained that, as far as she understands, racism isn't talked about in Mexico for four complementary reasons: 1) "Because in Mexico we don't talk about races, we talk about cultures and peoples", 2) that the word "racism" revolves around "race", such that 3) we prefer to use the word "discrimination" instead of "racism", and that 4) "maybe the whole racism thing is more recognized and... more visible in a place like the United States where they have black roots" (TR, 28112015).

In one of the reflective focus groups, Raquel shared that she felt a desire and commitment to transmit the reflections developed in the workshops into social practices that might transform her immediate environment, family networks, and friends:

I feel a lot of responsibility... to be able to share all of this that we are sharing, reading, and discovering in the best way possible. Because it's a challenge... in my family... there are racist ideas... I can't stay silent, but then there's the issue that, what if they get mad at me and don't want to listen? ... At this moment I feel this concern... of how to talk about these things so that other people say, 'well, yes, it's true,' instead of provoking the reaction of 'these damn radical chicks'... the latter is not my goal... we have to look at how to be heard" (TR, 28112015).

She also feels that in order to confront these inequalities it might be necessary to look at the problems from multiple perspectives, instead of just one, because "as we're looking at it now there are no solutions"; it might be necessary "to look at alterity from our own Otherness...so that we truly are a more inclusive society" (E2, 23062015).

Finally, to describe the borders between Self and Other, as well as to define themselves, Flor and Raquel revealed the way in which they construct subjects with an "indigenous" identity and how they construct themselves in relation to their imaginaries. For example, towards the end of 
the first interview with Flor, I asked her to indicate to what extent and in what order of relevance she identified with each of the categories of study. She chose "mestiza" first, then "indigenous", "black", "Spanish", and lastly, "Mexican". She explained:

I would put "indigenous" in second place and "mestiza" first because of how they are conceived. One imagines an indigenous person as someone who hasn't left their small village, who doesn't know how to move around in a big city; someone with little education, timid. This is what comes to mind when I see the word, "indigenous". Someone who needs to be protected. And I don't feel that way, I feel like I told you earlier, very independent... the interesting thing is that physically I consider myself very indigenous, more than mestiza... physically I feel more indigenous than mestiza... but I feel more mestiza in the sense of my relationship with my context, with me being cosmopolitan, knowing how to get around.

In our second interview, three months later, I asked Flor what percentage of "indigenous", "black", and "Spanish" blood she considered herself to have. The question emerged from an intervention by David, a Public Relations major, who voiced the imaginary that conceives of a purity of "the indigenous race" if "racial mixing" is avoided. Flor responded, " $80 \%$ 'indigenous Maya,' 10\% 'black', and 10\% 'Spanish"'. However, she clarified that she couldn't be sure because she never met her father nor his family; but she assured me with some pride that "culturally", from her mother's side, "we're more Maya than anything else".

Considering that Flor sees herself as physically "very indigenous", it's interesting that Olga, a Publicity and Public Relations major, doesn't consider Flor to be "indigenous" in appearance. It's notable that upon explaining her reasons, she said:

I'm not saying that an indigenous person can't study, but... I imagine an indigenous person in his or her house, maybe living off the land, animals, that type of thing (...) I mean, I'm not saying they can't go to school, but for example Flor, who lives here, who is in a feminist group, I don't know, I feel like these aren't indigenous activities, I don't know why.

On the other hand, towards the end of the interview with Raquel, I asked her to tell me in what measure and order of relevance she identified with the categories of study. Later on in the focus group she shared that upon having to choose she felt confused, with "serious identity issues":

I was like damn... then what am I? Because I don't see myself as indigenous since I don't speak the language or practice those sorts of things... although my parents are indigenous. However I feel that my features are native... so I have this problem of “I don't know who I am". But I think it has to do with my whole past of negating these things (nervous laugh). 
In the first interview Raquel had told me, "I don't identify myself as indigenous because even though I have a lot of affection for them and all that, I didn't grow up with certain things, with attachment to the community... I don't feel like an indigenous student, I couldn't come to say that'.

In this vein she told me that the categories that best describe her, in order of relevance, are: "Mexican", "indigenous", "mestiza", "black", and "Spanish". Three months later, in our second interview, she changed the order: "mestiza", "indigenous", "Mexican", "black", and "Spanish". However, she changed the order again when I asked her to say what percentage of "indigenous", "black", and "Spanish" blood she considered herself to have. She responded 70\% "indigenous", $25 \%$ "black" and 5\% "Spanish". She then said that the categories of study described her best in this order of relevance: "indigenous", "Mexican", "mestiza", "black", and "criolla".

\section{Final reflections}

The diverse identities of the students in the workshops made Flor and Raquel confront points of view radically different than their own. It brought them to ask themselves questions that they had never asked before and think about themselves in new ways. It brought them to reflect on the way they construct the Self and Other. This in turn brought them to discern patterns of inequity that reproduce the analyzed representations, as well as to question the legitimacy of the latter. Further, upon inspection of the media representations presented and observing the political ends that shape them, the focus groups helped name the racism that structures them.

In all, the process of investigation created the conditions to make visible the continuity through time of ideas and racist actions in the daily lives of the students. It also led students to positively value interaction with diversity and to affirm their identity based on a resignification and a re-evaluation of distinguishing stigmatized features. As a result, it made clear that "indigenous" subjects experience conditions of disadvantage, oppression, and exploitation with much more frequency and intensity than "mestizos", because "Mexicans" don't admit to having a racist way of viewing the world, even as the material and symbolic abuse of native peoples is a normalized practice and the equality that the national constitution supposedly guarantees "erases" from our collective memory the fact that since the Viceroyalty period we have inherited a social fabric fragmented in castes and a socioeconomic structure of domination over "indigenous" and "blacks".

Discriminatory actions against "indigenous" people are only the tip of the iceberg. Under the surface lies a complex system of symbolic representations that establish the hierarchy of domination that justifies the marginalization of native peoples. The national grammar of identity/alterity acts as a racist prescription of positions assigned to subjects and groups. Its political aim is to legitimize "mestizo" domination over native groups, constructing them so as to minimize, denigrate, deny, and reduce their dignity; and it does so in a naturalized, invisible manner, thus orienting the actions of subjects and groups. 
To reproduce the grammar of the system, schools and the family are two extremely important spaces of socialization, playing a huge role in the construction of subject identity. Nonetheless, in a context of struggle it's possible to implement educational processes that make visible inequalities in the national grammar of identity/alterity, and that, based on critical reflection, contribute to the construction of a national grammar of identity/alterity that is plural and horizontal.

To achieve this goal, popular and intercultural education, as well as critical media literacy, offer the necessary conceptual and methodological tools to structure educational processes geared to visibilizing and questioning inequalities and the systems of domination that produce them. For example, from critical pedagogy (Freire, 2011) it's useful to take up the pedagogical strategy of problematizing reality as a form of cultural action in order to dismantle structures of domination.

Intercultural education (Walsh, 2010) contributes the sensibility to identify conflicts and construct solutions with and from diversity in context; it also gives us the aim of visibilizing the causes of asymmetries and inequalities, thinking from the perspective of the oppressed and collaboratively constructing relevant critical knowledges. And from media education (Kellner and Share, 2007) we take a critical gaze on the influence of media and the possibility of visibilizing conflicts of class, gender, race, sexuality and political power from multiple perspectives.

Thus what I propose to call intercultural media education implies preparing students to unearth meanings that are below the tip of the iceberg. It also includes capacitating them to critically navigate the sea of textual, oral, visual, and audio discourses which surround them in all aspects of everyday life. It means creating learning environments that motivate them to initiate alternative forms of organization and grammars of identity/alterity that might construct horizontal and dialogic relations in the context of diversity. The latter contributed to the deconstruction of processes of social discrimination and the development of processes of identity reconfiguration based on critical reflection concerning the grammars of identity/alterity that underpin representations of diversity.

\section{References}

Anderson, B. (2005). Comunidades imaginadas, reflexiones sobre el origen y la difusión del nacionalismo. Mexico: Fondo de Cultura Económica.

Bolivar, Antonio and Jesús Domingo (2006). "La investigación biográfica y narrativa en Iberoamérica: campos de desarrollo y estado actual". In: Forum: Qualitative Social Research. Vol. 7, núm. 4. Berlin: Freie Universität Berlin.

Bonfil Batalla, G. (2010). México profundo, una civilización negada. Mexico: Debolsillo.

Castellanos Guerrero, A. (2005). "Para hacer nación: discursos racistas en el México decimonónico”. In: Gómez Izquierdo, J. (coord). Los caminos del racismo en México. Mexico: Plaza y Valdés, pp. 89-115.

Castoriadis, C. (2013). La institución imaginaria de la sociedad. Mexico: Tusquets. 
Cegarra, J. (2012). "Fundamentos teórico epistemológicos de los imaginarios sociales". In: Cinta Moebio, núm. 43. Santiago: Universidad de Chile, pp.1-13.

CONAPRED. (2011). Encuesta Nacional sobre Discriminación en México. ENADIS 2010. Resultados Generales. Consulted on April 2016 at http://www.conapred.org.mx/userfiles/files/Enadis2010-RG-Accss-002.pdf

Dietz, G. (2012). Multiculturalismo, interculturalidad y diversidad en educación. Una aproximación antropológica. Mexico: Fondo de Cultura Económica.

Dietz, G. and L. S. Mateos Cortés (2013). Interculturalidad y educación intercultural en México. Mexico: SEP-CGEIB.

Freire, P. (2005). Pedagogía del oprimido. Mexico: Siglo XXI.

Giménez, G. (2007). "Formas de discriminación en el marco de la lucha por el reconocimiento social”. In: Gall, O. (coord.). Racismo, mestizaje y modernidad: visiones desde latitudes diversas. Mexico: UNAM.

(2009). Identidades sociales. Mexico: Consejo Nacional para la Cultura y las Artes. Instituto Mexiquense de Cultura.

Gingrich, A. (2004). "Conceptualising Identities: anthropological alternatives to essentialising difference and moralizing about othering". In: Baumann, G. and A. Gingrich (eds.). Grammars of Identity/Alterity: a Structural Approach. London: Bregan.

Girola, L. (2012). "Representaciones e imaginarios sociales. Tendencias recientes en la investigación". In De la Garza Toledo, E. and G. Leyva (eds.). Tratado de metodología de las ciencias sociales. Perspectivas actuales. Mexico: Fondo de Cultura Económica-UAM.

Gómez Izquierdo, J. (2005). "Racismo y nacionalismo en el discurso de las elites mexicanas: historia patria y antropología indigenista". In: Gómez Izquierdo, J. (coord.). Los caminos del racismo en México. Mexico: Plaza y Valdés.

and M. E. Sánchez Díaz de Rivera (2012). La ideología mestizante, el guadalupanismo y sus repercusiones sociales. Mexico: UIA-BUAP.

González Casanova, P. (2003). Colonialismo interno: una redefinición. Conceptos y fenómenos fundamentales de nuestro tiempo. UNAM. Consulted on April 292016 at http://conceptos. sociales.unam.mx/conceptos_final/412trabajo.pdf

Gutierrez Chong, N. (2001). Mitos nacionalistas e identidades étnicas: los intelectuales indígenas y el estado mexicano. Mexico: Consejo Nacional para la Cultura y las Artes/Plaza y Valdés.

Kellner, D. and J. Share (2007). "Critical media literacy, democracy, and the reconstruction of education”. In: Macedo, D. and S. R. Steinberg (eds.). Media Literacy: A Reader. New York: Peter Lang Publishing.

Krieger, Peter. (2004). "La deconstrucción de Jacques Derrida (1930-2004)". Anales del Instituto de Investigaciones Estéticas, núm. 84, pp. 179-188. 
Molina Valencia, N. (2013). "Discusiones acerca de la Resignificación y Conceptos Asociados". In: Revista MEC-EDUPAZ, núm. III, pp. 39-63.

Ramírez Lozada, D. (2003). El amor a la patria en México, antropología de una pasión. Mexico: BUAP.

Rockwell, E. (2009). La experiencia etnográfica: historia y cultura en los procesos educativos. Buenos Aires: Paidós.

Van Dijk, T. A. (2003). "La multidisciplinaridad del análisis crítico del discurso: un alegato en favor de la diversidad". In: Wodak, R. and M. Meyer. Métodos de análisis crítico del discurso. Barcelona: Gedisa.

Walsh, C. (2010). "Interculturalidad crítica y educación intercultural”. In: Viaña, J., L. Tapia and C. Walsh. Construyendo interculturalidad crítica. La Paz: III-CAB. 